\title{
FOREWORD
}

\section{The Visitors' Question}

\author{
CARTER WILSON
}

FOR FIFTEEN YEARS, most of my opportunities to see the plays of the Monkey Business Theatre, Teatro Lo'il Maxil, have come about through the happy coincidence of being where the company was performing at the right moment. As a friend of cofounder Robert M. Laughlin and several of the original actors, I have always kept an eye on the performance's effect on the spectators, whether the show is Torches for a New Dawn presented in the plaza of Zinacantán for Mayan schoolchildren or Rogelio Román Hernández Cruz's The World Turned on Its Head acted before a glittery overflow crowd in the Salón Manuel Ponce at Mexico City's Palace of Fine Arts.

At the Theatre's San Cristóbal de las Casas headquarters in 2000, one select audience was made up of eight or nine North American indigenous artistsactors, dancers, poets, and a director-traveling together through southern Mexico to better acquaint themselves with Mayan culture, ancient and present-day. The room was not large, barely space enough for the backdrop curtain, the stage action, and some hard wooden chairs for the guests. The show Monkey Business presented that afternoon was When Corn Was Born, which features the fearsome red-coated Earth Lord, a scorpion, and a scad of scurrying ants played by finger puppets, plus kibbitzing and a helping hand for the poor humans of the piece from two of the ancient Mayan gods, portrayed by actors' voices and huge puppet heads peering down from above the backdrop.

Several of the visitors had been trained in New York and were acquainted with the style of Ralph Lee, who had been coming annually to develop and stage a play with Monkey Business Theatre. In the discussion following the performance, the guests asked how much of what they had just seen was Ralph Lee and how much came out of the troupe's own indigenous traditions.

At first, the actors did not answer. The question seemed to have generated some tension, as though the guests had reservations about what they had 
just seen. Then company member Juan de la Torre made a short speech, pointing out that the Maya have preserved their languages and culture through the more than five hundred years since the arrival of the European invaders. And this they have done, he said, in the face of heavy opposition and disrespect, and with virtually no help from government agencies or other outside sources.

Juan's speech pleased the Native American artists. They began offering songs in their own languages as thanks to the Monkey Business actors, and then there was an exchange of handshakes and abrazos all around.

Most people in the outside world are aware that the ancient Maya had a fully functional writing system based on glyphs, and many may know that the modern descendants of the Maya maintain a rich oral story culture. But they know less about Mayan literacy, written literature, and dramatic traditions, either in the deep past or the present. The following brief sketch of this heritage provides a good introduction to the Monkey Business Theatre's first collection of plays, especially since, even though they usually perform in Spanish, Monkey Business is an important contributor to a vital movement to revive Mayan literacy and literature and to keep Mayan culture vital.

On a July day in 1562, less than fifty years into the Spanish occupation of the Yucatán Peninsula, Friar Diego de Landa, a Franciscan, had five thousand Mayan idols destroyed at the town of Maní and burned the twenty-seven Mayan books he could lay his hands on. Though Landa could not read the texts, he was convinced they must be full of lies perpetrated by the Devil. At the time, Landa's newly converted Indian flock "regretted" the destruction of their books "to an amazing degree," as Landa noted. It caused them, he said, "great affliction."

The Mayan glyphic writing system was a key accomplishment of a civilization that was nearly two thousand years old when the Spanish came along. No one really knows how many people in the Mayas' city-states could actually read and write, but archaeologists think maybe only 2 percent could write, most of them men, but some women as well. Nevertheless, the relatively small number who were literate were key contributors to social life and included not only ruling lords and ladies, but also the astronomers who interpreted the past in order to predict the future, prized artisans, the medical practitioners who could divine your illness and cast it from your body, the storytellers, and probably some of the professional entertainers. Friar Landa reported that those who could read and write did not always tout their skill in public, but they would have books buried with them, presumably so they could use them again in the next life. 
From almost the beginning of their era, the Maya put writing everywhere: on brightly painted murals, on the carved stone pillars known as stelae, on the risers of magnificent flights of stairs, on the rims of ceramic pots, on carved seashell or polished bone jewelry, and even on the bodies of human figures in bas-relief sculpture. In scenes depicting court life, busy little supernatural writer rabbits scribble down the words of the powerful. When human scribes are pictured, they sometimes look harassed, with huge, messy clutches of pens stuck in their hair.

Even if only an educated elite knew how to produce the glyphs, ordinary people must have been able to comprehend much of what they saw on buildings and monuments. Public writing touted the accomplishments of rulers, thus functioning as billboards or character posters do in our times.

Reading and writing connected humanity to the divine. As poet Ámbar Past reminds us in Incantations by Mayan Women, the wife of the great god Itzamna was believed to have created the universe by writing it. The memory of writing's old power remains in modern Mayan beliefs and metaphors. In the Chiapas municipio of Zinacantán, the two unmarried scribes who keep the schedule for officials entering on religious obligations are known collectively as "the holy torch, the holy mirror."

The conceit that writing equals creating becomes even more resonant when we remember that in Mayan languages the acts of writing and painting are usually not distinguished from one another. The four rediscovered Mayan texts that the Spanish did not destroy bear little resemblance to modern mass-produced books. The pages, accordion-pleated like a road map, were covered in a white lime wash, then drawn upon and colored on both sides with a rich combination of writing, astronomical data, and intricate cartoon figures, most of them deities but often engaged in obviously human occupations such as digging holes and dropping in kernels of corn. No wonder the Maya who observed Landa's auto-da-fé at Maní were "greatly afflicted." It was their collective knowledge that the friar had consigned to the flames.

As colonizers, the Spanish found themselves with too few soldiers and priests to govern so large a native population effectively. Outlawing the old writing had symbolic force and was one aspect of a program to establish political and spiritual control through intimidation. During three centuries of colonial life and well into the modern period, limiting access to Spanish proved wise, as did the policy begun in the Invasion of emphasizing differences between Indian communities and keeping them pitted against one another. Without literacy, indigenous people faced enormous difficulties proving title to their land. Without "learning," Indians could not advance to the Catholic priesthood. 
Despite the cleverness of the whites (or Ladinos, as they are called in Chiapas and Guatemala), there were still attempts to overthrow the Europeans, notably in Chiapas in 1712 and 1867, and in the Caste War of Yucatán, which began in 1848 and divided the peninsula into hostile nations, Maya and white, for more than sixty years. In each case, the whites noted disparate and usually antagonistic groups of Indians banded together and went to war when they discovered they shared a grievance (an onerous new tax, an increase in the cost of baptism, land grabs by Ladinos). The Maya, however, conceived of the problems as belonging to the spiritual realm. In their view, they were more true to the teachings of Jesus than the Ladinos.

Though 150 years apart, the Chiapas insurrections were alike in that both began with young women, girls really, announcing they had been asked by heavenly beings to found a new, Indian-only religion. The wisdom of keeping Indians illiterate was verified by the fact that in all three rebellions the male leaders turned out to have had some education in Spanish. At vast public meetings during the Caste War of Yucatán, the wooden "Speaking Crosses" venerated by the rebels addressed the faithful in tiny voices (probably ventriloquized by men or boys hidden below or behind an altar). The Crosses also dictated letters to encourage or threaten their allies in distant villages.

The ban on indigenous literacy had never been absolute. Soon after the Europeans' military control was secured in the 1520 , the priests began tutoring a select few, mostly sons of Mayan caciques, in Spanish. The intention was to build a loyal cadre of literate Indian vassals to assist in maintaining control. Among the religious were a few who also put great effort into learning Mayan culture from their students, desiring to know their new charges' hearts in order to save their souls. But they were sometimes also dangerously drawn to the gentility and artfulness of Mayan daily life (ironically, Diego de Landa himself was one of these; he set his findings down in a manuscript dated 1566 called Relación de las cosas de Yucatan, which became the first book-length ethnography of a Mayan people).

Teaching Spanish to an elite few while prohibiting the old writing system had an unexpected effect. These Maya began at once to employ the new alphabet to save the old knowledge before it was lost. The Popol Vuh, the epic of the K'iche' Maya of highland Guatemala, was probably set down first in K'iche' around 1555. Its authors spoke directly to the urgency of their task and the necessity for secrecy since the old order had apparently passed away and the K'iche' were forced to live in the shadow of the Christian cross. In the Yucatán, incantations and spells to drive out illness were rendered in alphabetic Mayan toward the end of the eighteenth century in the El ritual de los Bacabes 
[The ritual of the Bacabes] (Arzápalo Marín 1987). Beautiful lyrics from before the Invasion, most likely originally sung in chorus, were preserved in El libro de los cantares de Dzibalché [The book of songs of Dzibalché] (Barrera Vasquez 1965). And throughout the colonial period, priests of the old religion continued under cover to write history in the preferred Mayan way. Since they conceived of time moving in great circles rather than in a line, events in what a European mind would conceive of as "the past" were often prophesied instead (the coming of the Spanish, for example, is "predicted" after the event). These works are found in El libro de los libros de Chilam Balam [The book of the books of Chilam Balam] (1963). Fourteen of them survive, and another five are known to have existed. Some of the Chilams were composed over several centuries, with a number of authors adding to each one.

Like the surviving painted books, many of the colonial Mayan texts were effectively "lost" for many years. Collected by antiquarians and European or North American travelers with little idea of what they had found, the works moldered away for centuries in libraries and manuscript collections. Their rediscovery and the new, better-informed readings of them in the second half of the twentieth century constitute the resurrection of a classic literature the outside world had little idea ever existed.

The rediscovery came during a critical period for the more than eight million modern Mayas of southern Mexico, Guatemala, and Belize. Along with other struggles, they now face the question of whether to continue living in traditional ways and speaking their own languages. The alternative would be to adopt Spanish (or, in parts of Belize, English) and the mindset of modernity. But when Mayan people make that choice, persistent racism almost inevitably forces them to enter mass society on the lowest rung of the ladder.

One reason that Mayan culture has endured in the Chiapas and Guatemalan highlands is that until very recently, indigenous people lived largely outside the national economies, called upon to link into them only as a part-time or seasonal workforce. In Chiapas, through the middle decades of the twentieth century, Indian men who could not make a living in the Highlands as corn farmers traveled down to "hot country" to pick coffee. In Guatemala, as Rigoberta Menchú (1984) recalls in her autobiography, whole families made the journey each year. In both countries, plantation conditions were barely human (the subject of Monkey Business Theatre's ironically titled Let's Go to Paradise!). Yet at least at the end of the contract the exhausted workers, often ill from hot-country diseases, went home to places where people spoke the same language and treated each other like human beings and not dogs. Today, for the million Maya who have gone to the United States in search of work, "home" is much farther away. 
Though the plantation system is not dead, in the last thirty or so years it has been superseded by a more encompassing economic order. In the new vision of governmental and global planners, indigenous people should not be differentiated from others in the great pool of mobile job-seekers and active consumers. Mexico's former president Salinas de Gortari's putting an end to the ejido system, through which the poor might still obtain land of their own, stands as only the best example of the neoconservatives' push. Traditional life comes under attack from all sides-as inefficient, embarrassingly backward, or, most simply, boring.

Not surprisingly, attacks often focus on language. Deprived of their bookcentered culture almost five hundred years ago, today's Maya are derided for their illiteracy and any hesitancy they have about learning Spanish. Otherwise well-informed journalists still describe indigenous languages as incomprehensible. As Robert Laughlin notes in this volume, a fashion persists for calling the languages dialectos, a way of making them appear less, somehow, than Spanish. In the 196os, when I was first studying in Chiapas, a huge billboard beside the main road into the Tzotzil communities announced that 200,000 indigenous people lived in these hills, "95 percent of whom remain ignorant of Spanish." The sign was the work of INI, the Instituto Nacional Indigenista (National Indian Institute), whose primary purpose was to aid indigenous communities through educational, health, and agricultural programs. In INI schools, beginning students were taught the written forms of their own language, but only as a way of introducing the Spanish phonemic system. After the first two years, instruction in Mayan disappeared entirely. As a government agency, INI's responsibility was to integrate Mexico's remaining Indians into the national economy, not to support tradition.

Despite such efforts, absorption of the Maya into the mainstream did not proceed at the desired pace, largely because Mayan-speaking people began to attain a new sense of themselves, both as Maya and as political actors. A civil war broke out in Guatemala in the mid-196os and continued at varying degrees of intensity for thirty years. The conflict made many Mayan people more critically aware that although they constitute a sizeable majority in the country, their share of national resources and citizens' rights is very small. When hundreds of thousands of them fled to the Mexican state of Chiapas to escape genocidal massacre at the hands of the Guatemalan Army in the early 1980s, the only people who housed and fed them at first were poor Mayan farmers like themselves.

In 1992, the state of Chiapas organized a grand congress of indigenous leaders from around the hemisphere to commemorate the 5ooth anniversary 
of the arrival of Columbus. The proceedings took place in the city of San Cristóbal de las Casas, a Ladino mountain bastion surrounded by indigenous municipios. During the congress, activists toppled a statue of Diego de Mazariegos, the conquistador responsible for subjugating the Highland Maya in the sixteenth century. The statue has not yet been put back on its pedestal.

Two years later, the armed Zapatistas appeared out of the Lacandón jungle and briefly occupied four Chiapas towns. Made up mostly of Mayas, the EZLN (Ejército Zapatista de Liberación Nacionál, or Zapatista Army of National Liberation) has since evolved into a political force with the aim of convincing the Mexican people to support autonomy and social justice for the country's indigenous citizens. Whatever else the EZLN may accomplish, it has galvanized consciousness among the Maya in Chiapas. For example, the five-day seizure of San Cristóbal encouraged Indians from the surrounding communities to treat the city as though it belonged to them even after the Zapatistas had melted back into the jungle. The change is much remarked locally, and by old-time San Cristóbal residents, with displeasure.

Approval of the Zapatistas in Highland Maya communities has been widespread but not universal. Generally, people in the poorer municipios have been more sympathetic. Those who are better off, like the Zinacantecs, or who have higher hopes for what the state or federal government might do for them, like the Chamulans, have been more circumspect.

Although the war in Guatemala and the Zapatista movement in Chiapas drew world attention, a less widely publicized effort to advance Mayan prideor, better said, to restore it-has also been made. In both Guatemala and Mexico, cultural activists are focusing on Mayan literacy and the creation of a new literature by indigenous authors. They are committed to the idea that their traditions and the thirty-one Mayan languages still spoken are noble assets, not liabilities. They employ classes in schools, radio and television programs, and theatrical presentations to revive languages that appear to be on the wane. Most activists imagine a synergized future in which the stigma of indigenous illiteracy will be entirely wiped away, and the Mayas will function equally well in their home languages and in Spanish. (In language politics, ironically, preservation is most often the progressive, or even the radical, course of action.) In Guatemala, indigenous linguists at the Academia de las Lenguas Mayas (Academy of Mayan Languages) worked out a unified orthography to replace the confusing historical higgle-piggle of styles that different transcribers had employed over the centuries. The result is a writing system that emphasizes similarities across Guatemalan languages, which advances pan-Mayanism by making it easier for a native speaker of one Mayan language to understand or acquire others. 
In its twenty-four years of existence, Sna Jtz'ibajom, Monkey Business Theatre's parent organization, has been heavily involved in offering adult education classes in Tzotzil and Tzeltal in the highland Chiapas communities. But since Spanish has become a lingua franca, especially for younger Mayas, Monkey Business decided on Spanish as the language for its plays in order to reach the widest possible audience. However, as Robert Laughlin points out in his chronicle of the Theatre's history, the actors themselves are so at home in various languages that at times they have agreed-in the van, say, on the way to give a show-to present that afternoon in Tzotzil, translating their own lines as they go along.

Though the plays may be performed in Spanish, the point of view is resolutely indigenous. It can be startling when Ladinos appear on the scene because of how completely Indian the world of the drama has been up to that moment. The indigenous characters are good and bad and struggle with moral issues, but the plays' Ladinos are stereotypes, comic windup toys who first appear menacing and then, usually, ludicrous in their unbridled greed or lust. The notable exception is the character of Erasto Urbina in Let's Go to Paradise! Urbina is a historical figure, considered a Ladino even though his mother was Mayan. In the 1930s, under a mandate from President Lázaro Cárdenas, Urbina worked to strengthen Indian communities as political entities and to get them out from under the thumb of conservative whites. A confrontational and apparently fearless individual, Urbina achieved the status of a hero among indigenous people for his advocacy in their favor.

The plays are presented here in the order they were created, between 1990 and 2003. This sequence allows readers to get a feeling for how the company responded to the changes taking place around them. The Zapatista offensive of January 1994 brought two-thirds of the Mexican Army into the state, as well as hundreds of journalists. Indian communities were forced to declare themselves "pro-Zapatista" or "loyal" to the Mexican government, a difficult and in some ways false set of alternatives. As Robert Laughlin points out, the Monkey Business troupe responded to the situation with plays that were more critical of the existing order. But they resisted the either/or of pro- or anti-Zapatista, understanding how that choice would polarize their home communities and work against a growing collective Mayan spirit. In works like From All for All they turned instead to traditional solutions, especially to the idea of restoring human concord through intelligence and compromise, and living in harmony with nature-all methods the old Mayan deities would heartily approve of.

As literary creators, Monkey Business members are in step with other authors who invoke the ancient Mayas' literary achievements and cyclical view 
of time to characterize their own movement as the rebirth of a writing tradition rather than as a cultural development imitative of European forms. Monkey Business's Jaguar Dynasty attempts to revitalize the legends of the old Mayas for their living descendants. Torches for a New Dawn undertakes a revisionist version of colonial history that features, among other things, Landa's burning of the books and the role of enforced illiteracy in the long oppression of Mayan people.

In his own introductory remarks, Monkey Business's Robert Laughlin recalls the early struggles that the troupe had in projecting their voices and gesturing "large," not at all the "proper," self-effacing behavior dictated by their upbringing. Laughlin also mentions how little experience of Western-style theatre the actors had to draw on at first. But if the definition of theatre is enlarged to include fiesta performances and some of the dramatic rituals of daily life, then today's Mayas are the inheritors of a long and, in some cases, uninterrupted tradition of drama and spectacle.

What is surprising about Mayan public celebration is how much the Europeans allowed it to remain as it had been before the Invasion. Again, a principal reason was the colonizers' inability to put an end to the natives' fiestas, together with their failure to understand how much of the old theology was embodied in the rituals. The events must have been grand in the old days-in his Relación, Diego de Landa describes occasions in the Yucatán in the 1540s and 1550 s when eight hundred men danced together in step to music.

One surviving verse and dance drama, Rabinal Achi: A Mayan Drama of War and Sacrifice (Tedlock 2003), takes place in an entirely pre-Christian world of heroes, royal captives, slaves, and Mayan gods. It is still performed today in K'iche' in the Guatemalan town of Rabinal. Dennis Tedlock, the play's English translator, says that for almost two hundred years during the colonial period, Ladino authorities repeatedly banned works like Rabinal Achí on the grounds that they contained references to the barbaric practice of human sacrifice. Such seditious plays remained popular, however, and Tedlock believes this is because they kept alive the memory of the time when the Mayas controlled their own society.

Diego de Landa commends the mimetic skills of native actors in his Relación. They would "hire themselves to the Spaniards for nothing other than to observe the jests the Spaniards pass with their servants, their wives, and on themselves" and would later imitate (or burlesque) their masters "with as much art as attentive Spaniards could" (36). 
Mayan murals and ceramic vases are populated with antic dancers, musicians, and comic actors in elaborate costumes. Archaeologist Karl Taube argues that many figures once thought to be part-animal/part-anthropomorphic gods are actually actors or dancers dressed as deities, with their human hands and feet visible under their fancy garments or their faces peering out from behind their masks. The distinction is subtle but valuable. If the paintings depict performances, they tell us more about which mythic themes got acted out in the old days.

Major characters found in the paintings have survived into the twenty-first century. The jaguar god, widely depicted, still prances through many modern Mayan festivities. Continuity from the time before the Europeans can also be traced in the ongoing observance of the old calendar's five-day evil or dangerfilled month called the uayeb, which marked the end of one year and the beginning of another. Mockery was apparently as potent a force in earlier Mayan society as it is today, and the uayeb was the period when ridicule could make its palpable sting in the context of laughter and buffoonery, with no harm done.

The ancient Mayas idealized their lords when they were young, portraying them in paint or stone as paragons of beauty and heroic character. But while respect for older people was a widely held value, as the "tired" old year was winding down, ageing rulers were subject to being made fun of. The uayeb fell usually in the month of February in the Gregorian calendar, near the Europeans' Carnival (Carnavál in Spanish, Mardi Gras in French). In Mayan-speaking towns in the Yucatán today, the pre-Lenten holiday is ruled over by a scamp named Juan Carnavál. In Tecoh, he plays scurrilous tricks to mock the authorities, such as leaving his bicycle outside the mayor's wife's window, implying that he is in her bed. In Hocobá, as Mayanist Victoria Bricker reports, when Juan and his cohorts are finally brought to trial for their misdeeds, their lewd responses to accusations about their drinking, stealing, and happily prostituting themselves to homosexuals make it obvious they are unrepentant. Whether Juan Carnavál is a European character or a Mayan one makes no difference since he so clearly represents a melding of Old and New World traditions.

On feast days in Europe the Church sponsored religious dramas performed for huge crowds, usually in the courtyard or on the steps of a cathedral or other great church. In Mesoamerica the priests imagined theatre as a way of converting the natives in large numbers and providing them with moral instruction. Often they wrote the plays themselves and then had them translated and performed by "their" Indians. In Momostenango, in the Guatemalan highlands, they still perform dance dramas that sixteenth-century Spanish Dominicans collaborated on with indigenous members of the old elite highly versed in classic 
Mayan cosmology. As a result, the nominal subject of an Easter week play may be the Passion of Jesus Christ, but according to anthropologist Garret W. Cook, the theme that comes out most strongly is the renewal of the Mayan year.

Less is known about how the pageantry of the highland Chiapas fiestas evolved. On the surface they resemble Spanish celebrations of Christian saints' days. Volunteer "religious" officials engage in long sessions of prayer, drinking, sharing meals, changing the vestments of the figures of saints, and bearing them from the church in public parades through the town. Other official groups organized on military models run clutches of huge, colorful cloth banners to and fro across the plaza. Music plays all day and into the night: ancient flute and drum; Spanish-descended harp, guitar, and violin; a hired brass oompah band-or all three at once, competing with the Mexican ranchera or hiphop music emanating from the bars and the stalls of hucksters in the market. Skyrockets whistle into the air and explode, and hand-held "bombs" go off like cannons everywhere. The Catholic church and the plaza before it are the focal point, and the people of the municipio the audience. But as in a multi-ring circus, several dramas may play out at once, some in the homes or courtyards of the officials, and others along the streets, up at springs or crosses in the surrounding hills, or down by the river. At peak moments, the whole town can be transformed into the locus of the action, which is fitting since the big fiestas are complex pastiches or collages of historical events and Mayan and Christian legends, not so much reenacted as recalled by allusion. Fiestas play out in "real" days and hours, of course, but they are also occasions when time (at least in the Western sense) comes unglued and everything happens at once.

As in Guatemala, fiestas in Chiapas are populated with many characters from Mayan rather than Catholic traditions. Figures such as the j'ik'aletik, or black men, and the max, or monkeys, are especially prominent in year-change or year-renewal festivities. Both j'ik'aletik and max have pre-Hispanic ancestry and disruptive duties: they frighten the children, make fun of authority, and feed the chaos, work which is also considered special and holy. Other characters - such as Nana María Cocorina in Chamula, a relentlessly lusty woman played by a man-come from regional history. "She" attempts to distract officials from their serious business by sitting on their laps and making lewd propositions. Anthropologists have accounted for the male transvestite actors as reinforcing conservative indigenous sexual norms by parodying Ladino women as wantons. A character like the bumptious, rude blonde secretary Socorro in Monkey Business's From All for All, who is played by a man and always gets big laughs, thus stands in a theatrical tradition well over five hundred years old of rude burlesquing of those in power. 
Just forty years ago, "entertainment" for indigenous people in highland Chiapas still consisted almost entirely of the spectacle of the fiesta and storytelling in the home. Today the range of choices is much broader. An adolescent boy at a fiesta can spend a few pesos to sit in a darkened room with his pals and watch Rambo movie videos. The soundtrack is broadcast outside to advertise the show, adding the voice of Hollywood schlock to the festive hubbub. With electrification, Mexican radio and television shows reach the municipios, and young people listen to their Walkmans as they hike the familiar paths home.

There are some promising uses for the newly available technologies. Local radio broadcasting in Mayan languages, for instance, contributes to communication between the communities and thus to Mayan solidarity. And traditional life may not be affected as much as we might imagine by the onslaught of mass media since indigenous people rarely find themselves reflected there. When an indigenous female "type" is called for in a TV advertisement, she is usually played by a light-skinned, blue-eyed young woman in pigtails — the pigtails being the chief clue to her being an Indian. The cliché about the Zapatistas is that they have been more effective as media specialists than as armed insurgents. Though their leader, Subcomandante Marcos, is not Maya, since 1994 the EZLN has provided the only voice widely heard for the 12 percent of Mexican people who are indigenous and for the country's great number of other disenfranchised poor as well.

In its own way, the Monkey Business Theatre also confronts the relative absence of a principled indigenous viewpoint in the larger popular culture. That their plays would each have a clear moral was a goal that emerged in the beginning of the group's creative process. A play, of course, will not reach an audience of the size the mass media can command. However, I am not thinking here of numbers, but of the experience of seeing the stories you grew up with dramatized, or the world you inhabit at last represented. This, I believe, is a principal reason Monkey Business plays are so enthusiastically received when they are staged in the municipios or for migrant workers living in bad conditions in rural Florida. Historical authenticity can be proven by tracing the antecedents of a creative endeavor, but another sort of authenticity is present when the work connects at once with what matters to its core audience. That is what the Monkey Business Theatre's plays have done now for more than a decade and a half. 